UDC 821.163.41-14.09 Sundečić J.

https://doi.org/10.18485/ms_zmskij.2021.69.1.4

Др Душко В. Певуља

\title{
ПОЕЗИЈА И ПОЕТИКА ЈОВАНА СУНДЕЧИЋА
}

На основу исказа иманентних пјесничком свијету Јована Сундечића, затим анализом његових ставова о природи поезије и смислу умјетничког стварања саопштених у предговорима пјесничким збиркама и неколиким чланцима, насталим пригодним приликама, у тексту се најприје успостављају могуће координате и константе поетичког концепта, пјесника, дипломате, свештеника и заслужног националног трудбеника Јована Сундечића. Знатан простор у расправи посвећен је и његовој биографској студији о Божидару Петрановићу, знаменитом представнику далматинских Срба у деветнаестом вијеку, личности која је умногоме одредила и судбину нашег пјесника. Затим су, у другом дијелу овога текста, анализиране главне пјесничке збирке Јована Сундечића и највриједнија умјетничка остварења у тим зборницима. Указано је на тематско-мотивски регистар Сундечићевог поетског свијета, на његову везу са доминантним стилским формацијама српске књижевности друге половине деветнаестог вијека те сагледан књижевноисторијски статус овог неправедно заборављеног пјесмотворца.

Кључне ријечи: Јован Сундечић, поетика, Божидар Петрановић, стилске формације, књижевноисторијски статус тематско-мотивски регистар, умјетничка обиљежја.

1. У својој крийичко-биоірафској сйуяији о Јовану Сундечићу, свештенику, пјеснику и дипломати, Марко Цар је одмах на почетку примијетио: „Нема можда српскога пјесника о којему се у Српству тако мало писало као о Јовану Сундечићу“ (ЦАР 1902: 1). У наставку истог текста, и поред изреченог, овај критичар закључује: „Па ипак ће име овога пјесника, покрај свих његових слабих страна, дуго живјети у успомени приморскијех Срба, а неке ће се његове пјесме [...] очувати међу најбољим производима српске музе у другој половини деветнаестог вијека“ (ЦАр 1902: 2). У до сада најбољој студији посвећеној Јовану Сундечићу, Марко Цар је критички одмјерено указао како на добре тако и на лоше стране пјесничког опуса овога ствараоца. 
Оптимистичке ријечи о његовој будућој пјесничкој судбини, изречене са много основа, нису потврђене у двадесетом вијеку. У оскудној рецепцији Сундечићеве поезије, као по неком правилу, наглашаване су њене мане, а прећуткивне непорециве умјетничке вриједности.

По многобројним и разноликим пословима те поетском гласу и обимном пјесничком дјелу (рачуна се да је по различитим часописима и у ауторским књигама публиковао око 800 пјесама), Јован Сундечић је био истакнута и поштована личност свога доба на знатном дијелу јужнословенског простора. А период кроз који се протеже његово разноструко дјеловање и књижевни рад јесте читава друга половина деветнаестог вијека. О Сундечићевом значају у нареченом периоду рјечито свједочи Сйоменица, која је 1899. године објављена поводом педесетогодишњице његовог литерарног рада (прву пјесму, под насловом Ананија и Сайфира објавио је у Зори gалмайинској 1848. године) $)^{1}$. У овој књизи обједињени су текстови о Сундечићу објављени у бројним јужнословенским часописима, у којима је изражено једнодушно поштовање према слављенику.

Јован Сундечић упокојио се 1900. године, а његово дјело ће недуго затим прекрити готово потпуни заборав. Приказујући књигу Петра Божовића под насловом Јован Сундечић, 1928. године у Летиойису Майице срйске, Крешимир Георгијевић је написао и сљедеће ријечи: „Ј. Сундечић иде међу оне наше старије песнике који су у своје време били много читани, док се данас једва зна за њихово име. Као и толики други, Сундечић је пао у заборав баш због онога због чега је највише слављен: подражавања народне поезије, и патриотских тирада и пренемагања. Време је прегазило продукте обичног манирског стихотворства, које у ствари нема никакве везе са правом поезијом. Појаве ових песника могу бити веома занимљиве још једино у културноисторијском погледу, као документ духовног настројења тадашње публике, и као прилог за упознавање нивоа њеног књижевног укуса и образовања“ (ГЕоргијевИћ 1928: 467-468).

Иако је овај суд о Сундечићевој поезији преоштар, вријеме које је долазило ипак је потврдило изнесене ставове. За њих је Георгијевић нашао упориште у Божовићевој књизи коју је представио, а у којој је аутор изнио више изразито негативно критички интонираних судова о Сундечићу. На једном мјесту у студији о Сундечићу Петар Божовић пише: „Као лирски песник Јован Сундечић није унапредио нашу лирику. Мотиви су његових песама опште ствари, а о каквој просечној уметности у овим песмама не може бити говора. Све су оне без маште и осећања, свуд је сув и хладан. Певао роду, љубави, или износио болове свога срца, он на нас оставља слаб утисак. Он се усиљава да се попне до праве лирике, али су му песме без вредности и он се безуспешнпо старао да нам остави стихове пуне живота и звука“" (Божовић 1928: 26).

${ }^{1}$ Јубилеј је обиљежен 1898. године, а Сӣоменийа је штампана наредне године. 
Дјело овог пјесника је у двадесетом вијеку потпуно маргинализовано, његових пјесама нема у најзначајнијим антологијским изборима српске поезије, споредно мјесто добија у Исииорији сритске књижевностии Јована Деретића, а појединачних радова о њему готово да и нема. Малобројни текстови у којима се Сундечић помиње најмање се тичу његове поезије, више су културноисторијског карактера. У ову групу спада текст Душана Вуксана под насловом Димийрије Рувараи и Јован Сундечић, објављен 1934. године у Летиоиичсу Майице срйске.

На начелно књижевноисторијско питање, које се нужно мора поставити послије наведених констатација, а које гласи: зашто једно књижевно дјело, признато и прихватано у вријеме појављивања, у неком другом времену, које нужно не мора бити нарочито временски удаљено, пада у потпуни заборав, одговор може бити крајње једноставан: зато што је то дјело мале књижевне вриједности, ефемерног умјетничког карактера, као и зато што се укуси и поетичке процедуре у одређеним временским циклусима мијењају. И један и други аргумент могли би се навести и поводом судбине књижевног дјела Јована Сундечића, али бисмо тиме остали ускраћени за релевантан одговор на напријед постављено питање. Српска књижевна историја биљежи и супротне процесе: бројна су књижевна дјела која нису била прихваћена у моменту објављивања, да би накнадно била реафирмисана и чак ушла у оно што бисмо могли назвати књижевним каноном. Довољно је само навести случај Лазе Костићћа и судбину његове најгласовитије пјесме па да се потврди речено. Укратко, књижевноисторијска свијест је, из читавог низа оправданих, али неријетко и тешко схватљивих разлога, селективна, због чега је списак заборављених и неоправдано скрајнутих српских писаца прилично обиман.

Да ли је у књижевноисторијским проучавањима, затим антологијским

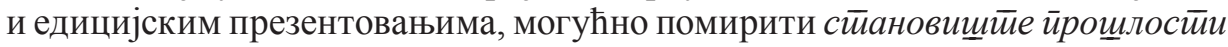

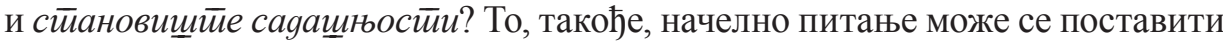
и поводом сагледавања и презентовања књижевног дјела Јована Сундечића, али и поводом судбине умјетнички репрезентативнијих писаца српске књижевности. Смисао књижевноисторијских реинтерпретација и ревалоризација подразумијева покушај одговора и на наведена питања, а у разматрачки комплекс укључује књижевноисторијске, књижевнокритичке, естетичке, аксиолошке и рецепцијске моменте.

Зато би се наша темељна дилема могла на сљедећи начин формулисати: Зашто је Сундечићево дјело било прихватано и цијењено у свом времену, која су унутрашња умјетничка обиљежја томе допринијела, зашто је недуго послије пјесникове смрти пало у готово потпуни заборав и, коначно, како се данас односити према томе дјелу, да ли оно данас посједује знатнију књижевну вриједност? Да бисмо назначили одговоре на комплекс наведених проблема, неопходно је најприје видјети какав је Сундечићев статус у најважнијим историјама српске књижевности.

У својој Повијестии књижевносиии хрвайске и срйске хрватски историчар књижевности Ђуро Шурмин биобиблиографским моделом уобличава 
портрет Јована Сундечића. Шурмин, међу осталим Сундечићевим пословима, издваја његово уређивање Далмайинскої иласника те издавање Качићевог Албума. Од појединачних пјесама Шурмин истиче Вpщugббу те нарочито подвлачи јужнословенску мисао којом је прожето ово дјело. На крају кратког одјељка о Сундечићу, овај историчар доноси и вриједносни суд о њему: „Његове се пјесме одликују љепотом облика, племенитошћу маште и дубином осјећања“"(Шурмин 1898: 183). Сундечићев књижевни рад, у својој Истиорији срйске књижевносиии, која је изашла 1903. године у Новом Саду, представља и Јован Грчић. Овај књижевни историчар доноси исцрпан приказ живота и рада Јована Сундечића, пише о тематској разноврсности његове поезије, али се не опредјељује за анализу или вредновање било ког појединачног његовог дјела. Грчић се тако односи и према другим писцима унесеним у своју књигу, ограничен књижевноисторијском концепцијом чији је био сљедбеник. Пореди ли се његово виђење Сундечићевог рада са начином обрађивања других писаца, видјеће се да је пјесник Крваве кощуље у поменутој књизи добио запажено мјесто (Грчић 1903: 136). Тихомир Остојић у своју Истиорију срйске кљижевностии, посмртно објављену 1923. године, не уноси Сундечића - тешко је закључити да ли због вриједносних критеријума или, што ће бити вјероватније, због тога што дио Остојићеве књиге у којем се обрађује новија књижевност није завршен.

У Истиорији нове срйске књижевносиии Јован Скерлић живот и рад Јована Сундечића приказује на готово двије странице. За разлику од других књижевних историчара - својих савременика, Скерлић се бави и вредновањем Сундечићеве поезије. Он за Сундечића каже да је био пјесник који се није мијењао те да је своје родољубиве мисли у пјесничком облику казивао „увек истим и монотоним стиховима“. Сундечић је, према Скерлићевој оцјени, неоригинални пјесник, подражавалац народне поезије, чије пјесме губе књижевни значај када се не сагледавају у контексту националних и политичких борби у чијој су служби биле. За Јована Сундечића Скерлић каже да је био „најпознатији и најчитанији српски писац код Хрвата““(Скерлић 2006: 257-258), а затим наводи оно што и сви други књижевни историчари прије и послије њега: чињеницу да је Сундечићеве Изабране ӥјесме 1889. године издала Матица хрватска.

Предговор за Изабране йјесме Јована Сундечића у поменутом издању написао је Хуго Бадалић. И он се усредсредио на исцрпан преглед Сундечићевог рада, али без упуштања у анализу појединих пјесама. На крају предговора Бадалић не разматра естетске вриједности Сундечићеве поезије, већ укратко излаже разлоге пјесникове популарности: „Но једно је већ данас утврђено, а то признају компетентни критичари и нашега и страних народа, да сав пјеснички његов рад носи на себи чисто народно обиљежје и да се особито одликује племенитом политично-народном тенденцијом, којој се наш пјесник никада и никоме за љубав није изневјерио“ (Сундечић 1898: 15).

Тако се према Сундечићу односе књижевни критичари и књижевни историчари - његови савременици. Какав је Сундечићев статус у историјама књижевности које су се појавиле у наше вријеме? 
Јован Деретић у Истиорији срйске књижевносиии Сундечићево пјесничко дјело одређује као „популарни народски облик романтизма“, а за његове пјесме каже да су писане „у једноставном течном али монотоном народном стиху, без дубине и оригиналности“ (ДЕРЕтић 2007: 708). Нама се чини да је најтачније књижевноисторијски статус Сундечићевог дјела одредио Душан Иванић у својој књизи Книжевности Срйске Крајине. Сундечићево дјело је, према Иванићевом виђењу, „фолклорна варијанта српског романтизма“, а он пјесник који се, супротно ономе што је тврдио Скерлић, мијењао, чак се показивао отвореним за разнолике утицаје. У Сундечићево пјесничко дјело укључени су разнолики фолклорни и историјски мотиви, карактерише га романтичарска полиметричност стиха те жанровски облици типични за ову епоху српске књижевности. Најзад, Иванић истиче и утицај српских пјесника на Јована Сундечића: Радичевића, Стерије, Његоша, Јакшића и других.

Поводом обиљежавања стогодишњице друштва „Сундечић“ из Ливна, у Бањалуци је 2007. године одржан научни скуп посвећен животу и раду Јована Сундечића. Тим догађајем је након више деценија његов опус постао предмет истраживачке пажње. Године 2009. у Бањалуци је објављен зборник радова под насловом Јован Сундечић: свещитеник, йјесник, дийломайа, у чијем су средишњем дијелу презентовани радови поднесени на истоименом научном скупу. Предмет научне пажње у засебним радовима била је разграната и богата политичка, просвјетна и дипломатска дјелатност Јована Сундечића, посебно сарадња са књазом Николом Петровићем, затим његова љубавна лирика, књижевноисторијски статус те књижевни прилози објављени у листу Црноїорка, који је на Цетињу излазио 1884. и 1885. године. Поред уводних, пригодних ријечи са отварања поменутог скупа, овај зборник садржи још и поједине текстове из рецепције Сундечићевог дјела, као и невелик избор из његовог пјесничког опуса (Сундечић 2009).

2. Јован Сундечић рођен је 6. јула 1825. године у селу Голињеву, покрај Ливна. Сундечићи су поријеклом из Требјесе, код Никшића, у Црној Гори. Када је имао три године, породица му се преселила у Далмацију. Године 1837. Турци су опљачкали и запалили имање његовог оца Пере Сундечића. Код фратара фрањеваца у Имотском научио је читати и писати, што се може сматрати првим корацима у његовом школовању. Два разреда основне школе завршио је на италијанском, код учитеља дон Петра Пеотија у Имотском. У Макарској је свршио основну школу, док је ћирилично писмо научио код православних калуђера у Главини. Намјера Сундечићевог оца била је да сина пошаље у манастир Житомислић да се закалуђери. Сундечићев сусрет са Божидаром Петрановићем био је од преломног значаја у његовој животној путањи. Петрановић га шаље у манастир Св. Арханђела, на ријеци Крки, код игумана Стевана Кнежевића, гдје је учио старословенски језик. Такође, по Петрановићевој препоруци, 1843. године уписује Задарску богословију. Поред богословских, Сундечић овдје учи и хуманистичке и философске науке. За вријеме школовања у Задарској богословији, Сундечић изрезује ситне 
слике у шимшировом дрвету и показује лијеп дар за ову врсту умјетности. Исказивао је у младости резачке, цртачке и сликарске способности. У часопису Словинац, у више наставака, крајем 1878. и почетком 1879. године, објавио је опширну студију о животу и раду Божидара Петрановића. На почетку тог текста Сундечић пише: „Два су човјека особито упливисала на мој душевни развитак у мојијем младијем добама. Један је Фране Салгети Дриоли (Salghetti Drioli), Задранин, вриједан и даровит сликар далматински, а други је др Божидар Петрановић, Шибенчанин, врсан домољуб и покретач народне књиге у Далмацији. Оба ова човјека већ су се упокојила. За њихова живота, обадвојицу сам високо цијенио, али им моје перо није никад поласкало; обадвојицу сам љубио, ал’ се је та моја љубав показивала само у изразима мојега према њима истинитога уважења. Њих више нема; ама је преостала у мени искрена харност, која ме је вазда одушевљавала према овој двојици мужева; према овијем мојијем добротворима. Нијесу ме они помагали ни сребром ни златом: помагали су ме свјетом и врлијем примјером. За таки очински зајам, зар би синовски дуг не подмирен могао остати?... Нипошто.“

Као стваралац се први пут оглашава у Зори gалмайинској (1848), у којој објављује пјесму Ананија и Сайфира. По завршетку Задарске богословије, 1848. године, Сундечић се оженио и запопио, након чега постаје капелан и учитељ у селу Пероје у Истри. У Задру 1850. године објављује пјесничку збирку под насловом Срие. Годину 1851. проводи у Жегару, као администратор парохије, да би затим био премјештен у Скрадин, гдје је двије године провео и истом звању. У Албуму, приређеном поводом стогодишњице Андрије Качића, објављује спјев Врщиияба, који је наишао на изузетан пријем и био објављен у више издања. Двадесет осам година касније написаће и наставак

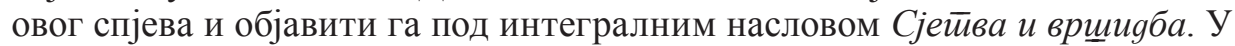
богословији ради до 1863. године. Сундечић је тешко поднио губитак професорске катедре у Задру. О томе како се осјећао, притиснут тешким материјалним недаћама, оставио је лирско свједочанство у својој значајној пјесми под насловом Јунак.

Епско-лирски спјев под насловом Крвава кощуља објављује 1864. године у Задру (ћирилицом и латиницом) у пет хиљада примјерака, што је за оновремене културне и издавачке прилике била несвакидашња пријатна ријеткост.

Са побратимом Миховилом Павлиновићем путује у Београд и том приликом посјећује сљедећа мјеста: Трст, Љубљану, Загреб, Ђаково, Вуковар, Сремске Карловце и Нови Сад. Код Јосипа Јураја Штромајера остају осам дана. Када је Сундечић са Цетиња путовао у Праг ради набавке штампарије, 1865. године, Шросмајер му као помоћ даје 3000 форинти. У Београду је Сундечићу Илија Гарашанин обећао мјесто професора. Лични секретар кнеза Николе постаје 1864. године, када се са породицом настањује на Цетињу. Три године доцније, накратко, одлази у Београд, гдје не добија обећано професорско мјесто. Враћа се на Цетиње и бива именован за државног секретара. 
За вријеме скоро десетогодишњег боравка на мјесту секретара кнеза Николе, Јован Сундечић обавља више запажених дипломатских послова. Написао је прву црногорску химну Убавој нам Црној Гори (1865), на чији текст је музику компоновао Чех Антон Шулц. Цетињски митрополит га је произвео за протопрезвитера с правом да носи напрсни протојерејски крст (1869). Исте ове године одлази у Беч да са представником руског посланства Рајевским договори статут за Цетињску богословију, коју исте године оснива, иако се поменути договори нису завршили успјешно. С кнежевом дозволом сам израђује статут, који ће доцније бити потврђен од Светог синода. У Бечу је боравио и 1871. године ради склапања више политичких конвенција (склапа погодбу за со, објашњава бечкој влади значај изградње колског пута од Котора до Цетиња и Ријеке Црнојевића, итд.). На политехничкој изложби у Москви (1872) упознаје се са бројним руским књижевницима и државницима.

Од 1874. године настањује се у Котору. Кнез Никола му даје отпуст, али остаје његов почасни секретар, са одређеном годишњом пензијом од 400 форинти. Руски цар Александар II додјељује Сундечићу доживотну пензију од 600 рубаља годишње. О Сундечићевом боравку на Цетињу Марко Цар је у студији о њему написао и сљедеће: „На Цетињу је Сундечић, малијем претргом од неколико мјесеци провео и кнежевој и народној служби мал'те не пунијех десет година, и те године спадају можда међу најбујније и најблагородније године његова пјесничког стварања. Сундечић се у то доба истиче као заносни гласник славе и јунаштва кршне црне Горе, и ту је улогу он сјано оправдао низом поетскијех саставака, у којијем се оно наше йоносит̄иo cйијење, скупа са народом својијем, огледа као слика у очињој зјеници“.

Године 1884. Јован Сундечић доживљава велику породичну трагедију,

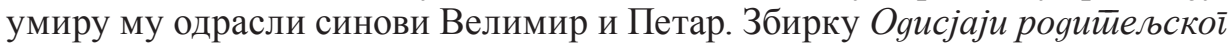
сриа (1885) посвећује тој личној несрећи. У предговору ове јединствене књиге наводи: „Она је још слатка одуга успомени двају синова, двају врлијех подмладака, које је зла и немила судбина, као двије ките и зелене гране, непоштедно од срца отченула старцу оцу и сјетној остарјелој мајци“. Након кратког увода, слиједе биографске биљешке о синовима Велимиру и Пери, а након Сундечићеве збирке и књига пјесама његовог сина Пера под насловом Срие и љубав.

Упркос пензионисању, наставио је да за црногорски двор обавља повјерљиве дипломатске послове. Треба посебно нагласити да је као црногорски пуномоћеник у Риму са Светом столицом склопио конвенцију о успостављању Барске католичке бискупије (1886) те да је издејствовао да се у католичким храмовима служба обавља на словенском језику.

Српска которска омладина је 6. априла 1898. године обиљежила педесетогодишњицу Сундечићевог књижевног рада. Наредне године је у Државној штампарији на Цетињу објављена Сйоменица посвећена овом јубилеју.

Свештеник, пјесник, дипломата, професор Задарске богословије, Јован Сундечић био је човјек велике радне енергије, покретач, уредник и сарадник 
бројних књижевних часописа. Уређивао је Гласник далмайински (1860-1861); у Задру је 1863. године покренуо књижевни лист Звијезgу. Након оснивања Матице далматинске постао је уредник Нароgної колеgара (за 1863. и 1864). Уређивао је црногорски годишњак Орлић (1866-1884). Био је власник листа Mahabarate, за уредника је именовао Симу Поповића. Од 1871. године овај лист је изалазио под називом Црноіораџ, а његов књижевни додатак назван је Црноіорка. Поред свега побројаног, уређивао је и цетињску Просвјет̄иy (1892-1894).

За свој рад Јован Сундечић добио је бројна одликовања и признања, међу њима и нека угледна инострана. Наводимо овдје да га је Српско учено друштво 1869. године именовало за свога почасног члана, што је 1893. године потврдила и Српска краљевска академија.

Јован Сундечић упокојио се 19. 7. 1900. године у Котору.

3. Јован Сундечић за живота је штампао скоро четрдесет засебних публикација, од којих знатан дио није био великог обима. Од пјесничких збирки треба посебно издвојити сљедеће: Низ драїоијених бисера (1856), Крвава

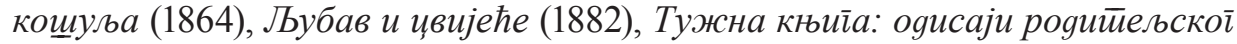
сриа (1885), Сјейва и врщияба (1888) те Миље и омиље (1893). Матица хрватска је 1889. године, у редакцији Хуга Бадалића, објавила Изабране ӥјесме Јована Сундечића. Тематски регистар обимног пјесничког опуса Јована Сундечића одликује изразита разноврсност, а треба примијетити да је интензитет његовог пјевања био у очигледној вези са преокупираношћу другим пословима (нарочито за вријеме службовања на Цетињу), као и са интимним животним околностима које су иницирале његово поетско исказивање. Писао је морално-поучне, родољубиве (снажно ослоњене на народну поезију) те љубавне пјесме. У напријед поменутом избору Сундечићевих пјесама у издању Матице хрватске и избору Хуга Бадалића, којим је Сундечићу учињена немала част, заступљене су пјесме које потврђују ову тематско-мотивску разноврсност.

Сундечићева поезија, која је по унутрашњим својствима најближа романтичарској поетичкој процедури (али се не може искључиво за њу везивати), темељи се на његовим најинтимнијим животним моментима, али су њени извори неријетко и лектирни. Сасвим је разумљиво, с обзиром на пјесниково школовање и боравак у Далмацији, што код њега привилегован статус имају италијански пјесници, чије стихове често узима за мото својих пјесмотвора или их на друге интертекстуалне начине, директно или посредно, уплиће у свој умјетнички свијет. То је толико учестало у његовим пјесмама да из манира прераста у неку дубљу унутрашњу потребу и духовну блискост са онима које призива.

Бројне су пјесме Јована Сундечића у којима овај пјесник тематизује само поетско стварање, што значи да је код њега, као и код других плодних и самосвојних пјесника, мисао о поезији неодвојива од самог пјесничког стваралаштва. Те мисли, заодјенуте у пјесничко рухо, издвојене и посматране 
засебно, представљају скуп занимљивих поетичких исказа, промишљања о поезији која нису насумична, јер нам откривају пјесника који слиједи свој пјеснички инстинкт и непрестано га освјешћује, па и онда када се угледа на друге, када је под утицајима (нарочито је видно и по пјесника штетно угледање на народну поезију).

О пјесничком стварању Сундечић проговара и у својим текстовима, бесједама или предговорима пјесничким књигама. У освјетљавању његове поезије и поетике, ти моменти морају се размотрити са нарочитом пажњом. У том смислу посебно је незаобилазна Сундечићева бесједа изговорена у Котору поводом стогодишњице рођења пјесника Симе Милутиновића Сарајлије. Тај повод Сундечић је схватио као прилику да ода почаст Сарајлији, али и да изнесе своје мисли о поезији и пјеснику, да у романтичарском духу истакне важност пјесмотворства. Већ на почетку свечане бесједе, вели наш пјесник, у духу ентузијастичке поетике, која своје коријене има у Платоновим научавањима, да је поезија искра божанстивеностии, а пјесник изабраник божије блаїоgейи, иророк, обличайељ свјетиских злоћа и нейравgи. Затим се наводе најславнији пјесници кроз историју и о њима износе крајње сажете али интересантне опсервације. Надаље, тврди Сундечић, йјесници су сииасоносни учииельи, блайовјесници, айостиоли, иооклоници бойу и људстиву; њихове задаће и обавезе су велике, јер су дужни „свом снагом и силом свога осјећања љубити: своју вјеру, своју домовину, своје име и свој завичај“. Занесени љепотом, њима је у задатку љейойу обожитии и својом часном љубављу

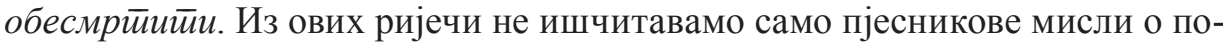
езији већ његов поетски програм, који ће он са још неколико важних компоненти допунити у бесједи о Сарајлији, али и потврдити, прије и послије изговореног слова, у свом пјесничком дјелу.

Важно је и његово пажљиво дистинктирање између пјесникових националних дужности и социјалне ангажованости, која неријетко склизне у простор политичке ефемерности: „С обзиром на тоิ, рекао је учени Француз Ди Шам (De Camp), да Пјесник много губи од свога угледа пошто се баци у вртлог политике. Но ја бих се и пак усудио ту Ди Шамову изреку овако исправити: Пјесник много губи од свога угледа, вазда, када се год баци у вртлог очевидне страначке политике, пошто у овоме случају неизбјеживо постане он неискренијем и неистинитијем. Али, кад Пјесник искрено и поштено, дјелом и словом, устаје на обрану свога и својине: у том случају, не само што ништа не губи од свог угледа; него, напротив, он, тај свој углед, на виши степен подиже и узноси““ (Сундечић 1893: 6).

Најзад, када је ријеч о Сундечићевим поетичким ставовима и промишљањима о пјесмотворству, вриједи овдје навести и његово запажање о међуодносу пјесника и филозофа: „Ох, предраги Боже!... у каквом ли је мистичком складу душа пјесникова са душом мудраца?!... Пјесник нас буди и подиже; а мудрац - учи и упућује. Пјесник нас заноси и соколи; а мудрац нас - снажи и укрјепљује. Пјесник нас одвија у поднебесне просторе; а мудрац нам указује способе да не клонемо у нашијем подвизима. Пјесник нам обогаћује и 
облагорођује срце; а мудрац ведри нам ум и бистри нам разум. И пјесник и мудрац најзад - кроз саму нарав упознају нас са врхунаравнијем бићем, од којега потичемо, ми и све; и којему се опет повраћамо, ми и све. Како философу - тако и пјеснику, мудрост је непресушиви извор надахнућа. Сваки жестоко гријеши, ко̀ год лучи пјесника од философа, и ко̀ год златну пјесникову машту запоставља философком оштроумљу. И као што би врло невољан пјесник без философије био: тако би и философ врло сухопаран био без икакве поезије у души; и славу, коју пјесник заслужује: исту славу заслужује мудрац и обратно“ (Сундечић 1893: 11).

На основу изложеног, могло би се примијетити да се Сундечић исувише удаљио од предмета своје бесједе, међутим, поводом Симе Милутиновића Сарајлије, кога сматра једним од наших најзаслужнијих пјесника, он је очигледно сматрао да треба да изложи своја умствовања о поезији, од којих смо најважнија непријед поменули. Сундечић наводи само неколике појединости из Сарајлијине биографије, наглашавајући да је његов живот био обиљежен сиромаштвом, што за пјеснике није необично, поред осталог и због тога што је за његову трагедију под насловом Кара-Ђорђије, која није била штампана, знао кнез Милош, и због које је код овог владара био у немилости. Од Милутиновићевих књижевних дјела у први план су истакнута три његова „пјесничка умотвора“: Милощ Обилић, Србијанка и Дика Црнойорска. Сундечић их, како је и прилика у којој се налазио налагала, само прегледно описује, али ипак у вриједносном смислу издваја Србијанку, за коју тврди, да нема језичких слабости, да би се „могла такмичити са најбољијем епскијем умотворинама“. Ипак, као највећу Сарајлијину заслугу Сундечић види то што је „српству подгојио славнога и неукога пјесника, владику Петра II Петровића Његоша; пјесника Горскоі вијенца, тога најбајнијега алема у круни просвећенога српскога пјесништва“. Бесједу поводом стогодишњице рођења Симе Милутиновића Сарајлије Сундечић завршава како и приличи овоме жанру, апелативно, позивом српском народу да се са више пажње и уважавања односи према својим истакнутим и заслужним појединцима.

Једном од Сундечићевих програмских пјесама може се сматрати она под насловом Пјесник, први пут објављена у Вили Стојана Новаковића, у Београду 1868. године. Хуго Бадалић у краткој биљешци поводом ове пјесме наводи: „Сјета, а у исто доба и оно охрабрење себи самоме, што се у њој тако бистро појављују, тврд су доказ тадашњег душевног немира пјесникова. Сундечић додуше бјеше стекао у Београду лијепу киту знанаца, који су се међу понајизабраније људе онда бројили, а особито га је омладина вољела и радо се с њим дружила, али сви су се знанци бавили, мање или више својим пословима, те се поријеђе могао са њима састати, а са омладином је морао бити на опрезу, јер влади није било по ћуди такво општење“ (СундЕчић 1898: 262-263).

Сундечићево тадашње стање и расположење неупитно је иницирало ову пјесму и одредило њен тон. Међутим, њен значај превазилази тај моменат настанка. Пјесник експлицитно наводи све оно што га подстиче на стваралачко 
исказивање, што побуђује његову инспирацију. У регистру тих чинилаца су: мио йойлеg, слаgак уздах, юежан осмијех, ријеч љубављу наяахнуйа, итд. Једновремено, у овој пјесми су истакнуте и повлашћене пјесничке теме, којима је више од других био предан овај стваралац: то су Бог, љубав, слога, народност. Инспирацију, пјеснички чин и настанак пјесме не изазивају само ови, за нашег пјесника опсесивни мотиви; благотворан утицај на настанак пјесме имају и туга и невоља, дакле, у поређењу са напријед наглашеним, потпуно другачији импулси. То се понајбоље види из сљедећих Сундечићевих стихова: И невоље истиомице/ Пјесника йоgбуgе/ Па му ӥјесме gивойнице/ Из њеgра заїyge. Душан Иванић је истакао да је на Сундечића утицао и Јован Стерија Поповић, међутим, он се није детаљније бавио анализом уочених веза између ова два, по одређујућим пјесничким својствима, различита српска пјесника. Сундечићеви стихови из пјесме Пјесник о тузи и невољи као подстицајним чиниоцима пјесничке инспирације, на очигледан начин се дозивају са познатим Стеријиним стиховима из пјесме Мојим иессмама, који

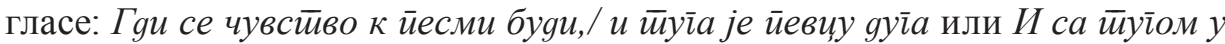
йрсима/ зачиғе се сиев и сииих (СТЕРИјА 1993: 15 - 16).

Слична поменутој је и пјесма Тражио сам, у којој, као и у већини Сундечићевих пјесама, веома поуздано може да се препозна пјесниково унутрашње душевно стање које је преточено у пјесму. У њој је стављен знак једнакости између пјесникових животних вриједности и његових главних умјетничких преокупација, док је у другом дијелу пјесме предмет пјевања постало све оно што онемогућава та пјесникова главна настојања. Пјесма Тражио сам завршава се у типично романтичарском заокружењу, у коме долази до изражаја пјесников пркос и супротстављање ономе што пријечи његове тежње, док кроз њену поенту пјесник поручује како живот и није ништа друго до поприште борбе, а не нека идеална оаза мира.

Поред бројних других пјесама које бисмо могли сврстати у овај круг, у којима се непосредно тематизује пјесничко стварање и моменти који са њиме конотирају, треба овдје поменути и сљедеће: Xajg'̄̄e, ӥјесме моје, Хaj, йјесниче, Миљь и омиљь, Ох, ӥјевај, Појиее, йојие, Да је риечи, Турим иееро и бројне друге. Треба скренути пажњу на занимљиву пјесму Да је риечи, која је посвећена опјевавању пјесникове инспирације, заноса и тежњи ка пјесничком исказивању, у којој, ипак, најснажнији утисак оставља пјесникова свијест о језичким ограничењима, о бранама које језик као медијум умјетничког испољавања пред умјетника поставља: „Да је риечи!... да искажем/ То што зна ми зачет миса':/ Дивно ли бих драги Боже,/ Онај занос описа““.

Различити утицаји, разноврсни пјеснички мотиви, елементи фолклорног те поетичке особине карактеристичне за српску поезију друге половине деветнаестог вијека видљиви су у многобројним Сундечићевим пјесмама. Умјетничка неубједљивост појединих његових дјела управо је условљена невјештом асимилацијом тих поетичких мијена на којима почива један сегмент његовог поетског свијета. То највише долази до изражаја приликом 
имитације народне поезије, затим у дидактичким и „ангажованим“ пјесмама, без обзира на то шта се у њима заступа.

Наведених слабости нису лишена ни у своје вријеме најпопуларнија Сундечићева дјела, она која су понајвише допринијела његовом пјесничком угледу, поеме Крвава комиљља и Сјейва и врщйбба.

Крвава кощуља објављена је 1864. године у Задру, у ћириличној и латиничној варијанти, у тиражу од пет хиљада примјерака. У жанровском смислу, Крвава кощуљља има готово сва обиљежја карактеристична за романтичарску поему: репрезентативни јунак стављен у средиште збивања, разоткривање његовог односа према другим ликовима, постизање циља коме претходи јунаково путовање, наглашена наративност и друге. Ова поема обрађује мотив мајчине заклетве сину да освети оца, који као покретачки замајац радње јунак понавља на више мјеста у дјелу. У ову поему, као уметнути одломци у односу према главном наративном току, укључени су детаљи из српске средњовјековне историје, као и карактеристична романтичарска амбијентација природе. Крвава кощуља се нетипично завршава, дидактичким додатком, графички одијељеним од остатка поеме, у којој је главни јунак испунио мајчин, али и шири национални завјет. Ти завршни

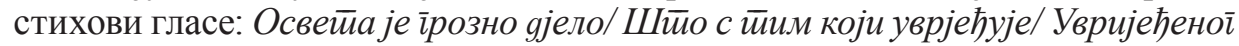
сйоређује/ Ма и мойли рећи смјело/ Да у часим коби хуgе/ Она нужном мјером

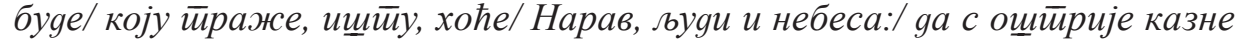
злоће/ И уйаре йороg бијеса (СундЕчић 1898: 175).

Најобимније Сундечићево пјесничко дјело, поема Сјейва и врииияба, представља, надасве, снажан позив на јединство јужнословенских народа, које се у организацији дјела преплиће са етапним приказивањем послова сјетве и вршидбе, као предуслова људског биолошког опстанка. И у овој поеми су веома експлицитно, неријетко наглашено тенденциозно, изнесена главна пјесникова програмска настојања, варирана на неколико начина и прилично развучена. Добро осмишљен и успјешно завршен посао око сјетве и вршидбе, постигнут слогом и садејством, у дјелу је представљен као модел људске и братске заједнице, односно природног окупљања јужнословенских народа.

Треба нагласити да је у основи ових дјела, којима је иманентна поетска тенденциозност, идеја ширег јединства југословенских народа, а не српскохрватско заједништво, аустријски концепт југословенства који је тријумфовао у двадесетом вијеку, да би у истом стољећу доживио свој историјски пораз. Нема упоришта у чињеницама из живота и дјела Јована Сундечића да се та политичка доктрина за њега везује, као, уосталом, ни за Божидара Петрановића, једног од најугледнијих далматинских Срба деветнаестог вијека, о коме је Сундечић написао књигу и према коме је његовао нарочито поштовање. Примјер како су погрешно тумачени Сундечићеви ставови о заједништву словенских народа представља један одломак из књиге Петра М. Божовића Јован Сундечић. Божовић пише: „Сундечић се у песми није зауставио на узаном патриотизму само према Црногорцима и Црној Гори. 
У првим његовим песмама осећа се идеја Славјанства, јер је он и пропевао као Славјанин, а после је постао Срб-Хрват, који у песми није правио никакве разлике између ова наша два народа. По своме певању овај православни свештеник био је најближи католичким Хрватима од свију Срба свога доба““ (Божовић 1928: 18). Први и други дио донесеног цитата у очигледној су противрјечности. Први је тачан, други произвољан. Да би поткријепио Сундечићевим стиховима други дио свог тумачења, Божовић наводи стихове који га радикално оспоравају, оснажујући опсервацију о пјесниковом славјансииву: Срб Хрвайу нека/ Брайску руку ирружи/ А Хрвай са Србом/ Нек с искрено gружи./ Словенаи у коло/ Наще нек се хвайа/ Буїарин међ нама/ Нек си бира брат̄а (Божовић 1928: 19).

За тему о којој овдје расправљамо ово су ванредно илустративни и драгоцјени стихови. Укључујући у словенско заједништво Словенце и Бугаре, Сундечић се показује као заступник српске идеје југословенства, чији су заступници средином деветнаестог вијека били Теодор Павловић и Јован Суботић, а која је рачунала са узајамношћу свих јужнословенских народа, дакле, не само Срба и Хрвата. Да се Хрвати према том заједништву нису искрено односили види се из стиха: $А$ Хрвай са Србом/ Нек с искрено яружи, а још више из његове књиге о Божидару Петрановићу, у којој се на више мјеста исказује сумња у хрватску приврженост идеји слоге два блиска народа. На тврдњу Анте Старчевића да је српски језик свиғски, Сундечић пјеснички надахнуто одговара: Није свиғски језик срӣски/Неіо језик - злайни језик./ Језик вила йјевачица/ Језик сийних йамбурица:/ Гибак,/ Глаgак,/ Звучан,/ Слаgак,/ Боїай,/ Јеgap,/ Крјейак,/ Веgар (Божовић 1928: 24). Бранећи српски језик од оваквих опадања, Јован Сундечић не пристаје на његово преименовање, на чему је почивала филолошка платформа аустријског југословенства.

4. Четири године након смрти Божидара Петрановића, Сундечић објављује студију у којој доноси исцрпан приказ живота и рада ове истакнуте личности и представника далматинских Срба у деветнаестом вијеку. Расправу под насловом Живот̄ и pag gр Божияара Петирановића Јован Сундечић је у осам наставака објавио у дубровачком Словиниу, овим редослиједом: број 12, октобар 1878. године, стр. 124-126; број 13, новембар 1878. године, стр. 141-143; број 14, 16. новембар 1878. године, стр. 158-160; број 15, 1. децембар 1978. године, стр. 176-177; број 16, 16. децембар 1878. године, стр. 188-189; број 1 , 1. јануар 1879 . године, стр. $12-14$; број 2, 16. јануар 1879 . године, стр. $22-25$; број 3, 1. фебруар 1879. године, стр. 40-45. Под истим насловом, у форми књиге од 75 страница, студија је објављена у Дубровнику, у два издања (1878. и 1879).

Студију о животу и раду Божидара Петрановића, која заузима посебно мјесто у његовом стваралачком корпусу, Сундечић започиње изражавањем дубоког поштовања и осјећајем дуга према некадашњем добротвору, чији ће савјети дјеловати прекретнички на његов живот и рад. Одмах истиче да 
му је намјера да прикаже Петрановићеве списатељске способности, његове грађанске врлине и усрдност у вршењу чиновничких дужности те, најпослиje, „жаркост његова родољубља“, укратко, да „подигне споменик“ (Сундечић 1878: 124) његовим заслугама. Како нас одмах на почетку информише, Сундечић своју студију темељи на личним контактима и учествовању у заједничким пословима са Петрановићем, затим на некрологу који је поводом Петрановићеве смрти објавио Фрањо Рачки те коришћењу података и запажања из Петрановићевог кратког аутобиографског списа. Сундечићев приступ је врло једноставан: хронолошким редом напоредо приказује Петрановићев живот (са посебним нагласком на његовом школовању), књижевни рад и бројне друге активности које обухватају више подручја.

Петрановић је рођен 1809. године у Шибенику, у породици која је старином из Дрниша. Школовање започиње у фрањевачком самостану, у којем учи читање и писање на италијанском језику. Потом га отац одводи у доминикански манастир, у којем му отац Алборгети предаје италијанску и латинску граматику, као и реторику. Није необично што су православна дјеца одлазила на школовање у католичке манастире, јер других училишта у то вријеме у Петрановићевом ширем завичају није било. Сундечић наглашава ту чињеницу јер је и сам прошао практично сличним путем. Већ након годину дана (1819), Петрановић наставља школовање у приватној школи фратра Бонавентуре Пинице, у којој учи италијанску и латинску граматику, математику и географију. На Петрановићево васпитање и потоње школовање велики утицај имали су утисци из најранијег дјетињства и прве спознаје у родитељском дому, о чему и сам свједочи у своме аутобиографскоме спису: у побожности и патриотизму угледао се на оца, који је био „ријетки побожни родољубац“" (Сундечић 1878: 126). Гимназијско школовање Петрановић завршава у Сремским Карловцима (1820-1826). Похађајући гимназију у Карловцима, према властитим ријечима, марљиво чита српске књиге и обилази фрушкогорске манастире (у нарочитом сјећању му остаје Шишатовац). Из Карловаца са оцем путује у Беч, а затим у Грац, гдје двије школске године (1827-1828) студира филозофију и усавршава њемачки језик; у Бечу три године студира право (1829-1831); Беч, који је био пред опасношћу од колере, Петрановић напушта 1831. године и одлази у Падову, гдје окончава четврту годину права. У Падови 1833. године Петрановић стиче докторат из области права, па одмах ступа на службу у суду у Задру.

Године 1839. Петрановић се прихвата државне службе и почиње да ради у сплитском суду; док је од 1842. до 1846. службом на Вису. У овом периоду вриједно ради на изради различитих чланака, на српском и њемачком језику. Поред осталог, води полемику са Николом Томазеом поводом Доситеја Обрадовића и његовог односа према традицији. Као заступник книнске, обровачке, дрнишке и врличке општине, Петрановић је изабран за посланика у Бечу, а затим и у Кромјерижу. Као посланик, свјестан важности тог положаја и могућности које он пружа, Петрановић постиже запажене резултате: „У Бечу а посље у Кромјерижу (Kremsier), као посланик при Сабору, 
настојао сам својски да се славјанској народности у Далмацији правица учини и да се равноправност набљудава. Израдио сам тај конац да се језик наш, као облигатан у гимназије уведе; предложио сам да се за славенски народ политички лист издаје, што је и уважено било; да се поунијатившим се њеким породицама допусти да се у своје старо благочестије поврате (види у 'Магазину' писмо моје министру Стадиону и одговор његов). Говорио сам јавно у сједници да је крајња потреба да се у Босни консулат аустријански опет установи, а у Мостару вицеконсулат, што је посље мало времена у дјело приведено [...] У Кромјерижу зачео сам такођер идеју да се у Далмацији Матица далматинска утемељи. Усљед прогласа мог скупио сам до 761 фор. које позније, због наставше промјене у систему владања аустријанског, морадох положити у Загреб, да се придрже у ондашњој Матици, али под тим условом, да се иста главница повратити има у случају да би Далматинци Матицу у отачаству подићи хтјели““ (Сундечић 1879: 12).

Петрановићева социјална, политичка и културно-просвјетна платформа лијепо се види из његовог списа-писма Мисли о Далмации, намијењеног бану Јосипу Јелачићу. Наведену разрађену и паметно осмишљену стратегију Сундечић овако описује, задржавајући се на њеним најважнијим мјестима: „Укратко, врли и умни наш домородац тијем списом настоји да сврати позорност бана Јелачића на запуштено шумарство у тужној његовој домовини; на слабо земљедјелство; на неваљано кметинство (sistema colonico); на пријеку потребу од земљедјелскога закона (legge agraria); на основање главница̂ (capitali); на заведење земаљскијех табла (Landtafel); на оживотворење катастра; на подизање учионицаิ о земљедјељству, и на раздавање награда̂ тежацима, који боље настоје око унапређења земљедјелства и побољшања живежа; на пресушење подводнијех поља, особито книнскога, сињскога и неретванскога; на новчану државну помоћ у свијем овијем подузећима; на дужност државе да настоји около развитка извора̂ за благостање; на изображење народно и народнијех учитеља, и за изображење свештенства о државноме трошку, са особитијем призрењем на биједно православно свештенство; затим на потребу увођења оштријех закона и хитнога правосуђа, да би се што брже претекла злочинства у покрајини; на укинуће разузданијех пандура (forzza territoriale); и најзад, на потребу да судије далматинске познају народни језик. Ово је све са живијем бојама нацртано и попраћено зрелијем и темељитијем мислима, како би се свему могло помоћи и доскочити. У посљедству времена влада се је готово на све ове предмете у Далмацији освртала и већом их страном оживотворала. Ко зна да овај спис није био влади згодан и добар у томе путовођа?““ (Сундечић 1879: 13).

У Бечу 1853. године Божидар Петрановић објављује књигу $O$ аустиријанском ірађанском законику и србскоме ирревоgу, у којој на једном мјесту расправља о српскохрватским односима. Сматра да ће вјерске разлике између Срба и Хрвата бити превазиђене посредством заједничког језика: „Ако је различан вјерозакон - вели он - толико дуго времена источне и западне цркве Далматине растављао, једнога од другога отуђивао, њих у напредак 
треба један свим обћени језик да међусобно веже“ (Сундвчић 1878: 159). Заговорник тог јединства, он га не посматра некритички те увиђа да се оно тек спорадично остварује и да се чешће разграђује. Треба нагласити, нарочито након искустава са југословенском идејом у двадесетом вијеку, да Петрановић рачуна са ширим заједништвом блиских словенских народа, а не са југословенском концепцијом која је подразумијевала наводно братство искључиво Срба и Хрвата.

Године 1850. Фрањо Јосип I именује Петрановића за покрајинског секретара, док двије године доцније бива постављен за савјетника суда у Котору. Био је члан Српског ученог друштва и Југословенске академије знаности и умјетности. Божидар Петрановић упокојио се у Венецији 11. септембра 1874. године.

Посебну пажњу Сундечић у својој студији о Петрановићу посвећује његовом књижевном раду. Као писац Петрановић се објавио „Одом на дан рођења Цара Франца I“, испјеваном 1831, а објављеном у Алманаху 1835. године. Сам Петрановић доцније биљежи колико му је био важан овај корак, иако о пјесми нема високо мишљење. У Лет̄ойису Майице срйске 1831. године објављује Писма Шибенчанина. За Ogy Сундечић напомиње да није имала књижевне вриједности, будући да Петрановић и није био пјесник, док потпуно друкчије вреднује Писма Шибенчанина, подупирући свој суд запажањем Емила Чакре, који је за ове епистоле рекао да заслужују „бесцена спомена“(Сундечић 1878: 159). Сундечић додаје да у њима долазе до изражаја Петрановићеве родољубиве мисли о добру и напретку властите земље, као и његово познавање њене „повеснице и старожитности“ (СунДЕчић 1878: 159).

Као посебну драгоцјеност ових Петрановићевих првенаца, Сундечић истиче то што су штампани на српском народном језику. Сундечић на сажет начин, али прегледно и прилично тачно, сјенчи филолошку стварност тридесетих и четрдесетих година 19. вијека, са нагласком на проблем још увијек некодификованог књижевног језика. Он напомиње да се до Доситеја у српској књижевности писало једном мјешавином ,словенског, црквенословенског и руског језика“; први Доситеј тежи да пише народу ближим језиком, али се ни он сам није могао лако ослободити „црквене словенштине“; трећи језик је славеносрпски, који је писан црквеном ортографијом. И у Петрановићевим првим књижевним покушајима огледа се та сложеност језичких прилика код Срба, с тим да се он, с појавом Вука Караџића и његових реформаторских дјела, опредјељује за језик који је Вук стандардизовао.

У Новом Саду, 1858. године, Петрановић штампа своје дјело Истиорија

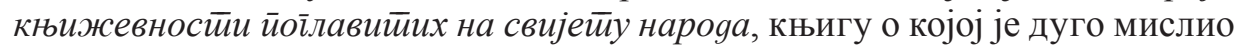
и за коју се деценијама спремао (један одломак из ове историје објавио је 1834. године). О мотивима да напише ово дјело Патрановић биљежи: „Огањ и љубав к правом изображењу и просвјети, њу на читање и учење старог и новог времена класика примами, и пут јој покаже по ком би чисти утанчани укус, од ког добро одгојење највише зависи, задобила и њега што више 
усавршила“ (Сундечић 1879: 13). За књижицу Боїумили, ирква босанска и крићћни Петрановић је добио награду од Српског ученог друштва из Београда, које је претходно расписало конкурс за рад на ову тематику. Не представљајући посебно ову студију, Сундечић наводи позитивну оцјену коју је о њој изрекао Фрањо Рачки, сматрајући је „наприедком у овој части црквене повиести“.

Од 1835. до 1839. године Петрановић је на позив владике Пантелеимона Живковића био секретар „православног Ординиријата“ у Шибенику. У томе периоду он заснива и библиотеку православне општине у родном граду, дарујући јој 600 властитих књига. Године 1835. Петрановић започиње издавање поучно-забавног годишњака под називом Љубииеељ йросвјешииенија срииски gалмайински Алманах, који под тим назвим излази те и наредне године (штампан је у Карловцу). Под измијењеним насловом Љубийељ йросвјешименнија србско-яалмайински Маїазин, наставиће да излази у Задру, са великим Петрановићевим пожртвовањем, који, упркос томе што је имао 456 üреgбројника за ово гласило, како свједочи, издваја и властити новац за његово редовно излажење, чије је мјесто веома важно у историји српских периодичних издања. Наведени Петрановићеви напори око издавања Маїазина још више добијају значај кад се има на уму чињеница (на којој инсистира Сундечић) да је Далмација у овом периоду „талијанштином поплављена“. Божидар Петрановић Маїазин уређује до 1841. године. О томе шта га је мотивисало да покрене ову публикацију, у своме аутобиографском спису пише: „На издавање 'Магазина' једина ме ревност и љубав рода мог руководила; јер сам за вријеме уредничства мог више од 600 фор. из собственог џепа типографим платити морао. Око 240 фор. остало ми је до данас од предбројника неизплаћено“ (Сундечић 1878: 159).

Оцјењујући значај ових публикација, Сундечић их тачно одређује као „енциклопедијске зборнике“, које је одликовала садржајна разноврсност, при чему су доминирали радови из историје, из књижевне прошлости, затим географије, просвјете, историје језика и обичаја, итд. Истовремено, Сундечић посебно издваја поезију, књижевне прегледе и различите, како их он назива, смјесице. ${ }^{2}$ Као што се може закључити на основу структуре, жанровског и тематског регистра заступљених прилога, Петрановић је прихватио поетички модел скоро типичан за слична издања његовог времена, а који је још у Славено-срйском маїазину 1768. године установио Захарија Орфелин.

${ }^{2}$ Од радова које је Петрановић објавио у Майазину Сундечић издваја сљедеће: Къи-

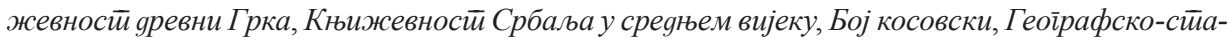
йисииччки йреїлеg Далмачије, Фамилија Јанковића и Смиљанића, Ояломии из иситорије йравославне иркве у Далмацији, и друге. Сундечић напомиње и да је неке вриједне књижевне прилоге Петрановић објавио под псеудонимом Веселин Сједоглава. Сундечић наводи и наслове Петрановићевих појединих значајних радова из области права: $O$ робстиву, O йpaву насљеgстива кол Срба на основу йравноїа обичаја и ииссаних сииоменика, О кмейсииву ӣо

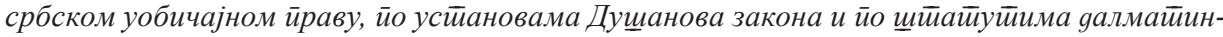
ских іраяова и друге. 
На Петрановићев приједлог, 1860. године, обиљежена је стогодишњица рођења Андрије Качића Миошића, и том приликом је у његову част објављен Албум. Његовим заслугама, те заузимањем Ивана Данилова и Ивана Брчића, у Задру је 27. јуна 1862. године основана Матица далматинска, за чијег предсједника је изабран Петрановић. Већ наредне године покренут је Нароgни колеgар, чија је два годишта уредио Сундечић. На челу Матице далматинске Петрановић је био дванаест година и за то вријеме је штампано дванаест Народних колеgара, као и девет „поучних књижица“, у национално-просвјетитељском маниру свога времена, према приликама које је оно неодложно наметало.

Завршни одломак Петрановићевог животописа, објављен у Словиниу 1. фебруара 1879. године, који је и најобимнији, Сундечић посвећује Петрановићевој краткој болести и смрти у Венецији, а затим одјецима које је његово упокојење изазвало у Шибенику, у читавој Далмацији, али и на јужнословенском простору. Сундечић евидентира те одјеке како би показао колики је Петрановићев углед био у његовоме народу и колико се осјећао његов губитак. У завршном дијелу студије Сундечић описује Петрановићев физички изглед и његов карактер, истиче радну енергију, наводи списак његових кореспондената, а затим и један укупни заокружен суд о овој изузетној личности српске културне и политичке повијеснице 19. вијека: „Узмемо ли га као књижевника, ето нам велик сноп његова врснога и умнога рада необориво потврђује његове озбиљне напоре и његова улагања за нашу књигу, за наш језик и за нашу просвјету. Да би се тој нашој књизи прибавила чврста и стаменита потпора, живом се душом заузима он и успијева да оснује Матицу далматинску. Петрановић својијем књижевнијем радом учи, зиђе, подиже, узвишује, облагорођава и чупа што не ваља, обара што је трошно, размеће што је неспретно и некорисно, води к истини, правди и љубави. Позлаћује народне обичаје; освјетљује народну повјесницу; отргује зубу времена народне старине и народне светиње и подгаја народну ријеч, као што се ружа у градини гоји. Он мудрац, пун практичне мудрости, неће да премудрује, ни да се размеће, као неки новији наши писаоци, који до миле воље насркани туђинскога трулежа - док збиља мисле да народу свом отварају очи, износећи му на углед неке пуке претјераности и занесености већ презорјеле цивилизације - они народу копају те исте очи, да се сиромашан, ка да му је на врату мало јада и невоље, још и брже суноврати и у понор скотрља. Обарати је лако, ма с кога краја да почмемо; али није лако градити, а да зграда тврда и становита буде. Томе треба чврста темеља, умјетне распологе, изврсна и добра градива, вјештине у работи и крепка настојања около предузетога посла. И по томе наш Божидар спада међу најбоље и најразумније раденике и пословаче у дјелу народне просвјете и у руковођењу народа на што виши ступањ његова правога и постепенога развитка и изображења. Најзад, узмемо ли Петрановића као званичника - пошто се за час осврнемо на околност да у оно доба, кад се је он државне службе примио, у свој Аустрији, а особито још у нашој Далмацији, сви неримокатолици бијаху уопште 
сматрани као нека једва трпљена пасторчад - онда нам је признати да су саме изврсне јуначке способности, уз приљежно, савијесно и вијерно вршење дужности у дјелима себи повјеренијем, Петрановићу рашчистиле стазу у помицању на већа државна звања. Он је, као што знамо, достигао до столице призивнога савјетника и до почасти дворскога савјетника. Риједак појав! - он је знао да буде и добар чиновник и искрен родољуб. Здушно је владу служио, а здушно је и на срећу народа радио. Но ипак није постао пресједником Апелације у Далмацији, чега је, мимо свакојега свога премца, заслуживао као вриједан законоша, и као познавалац народнога језика, и као на реду и по годинама службе тада најстарији савјетник. Ама, влада је добро знала ко је Петрановић у души и колик је он патриот; па, ако се је и користила с ријеткијем његовијем способностима уз тврди наслон на његово поштење, ипак се је устегла да му одлучно повјери врховно достојанство у покрајини. Чудна је то ствар!... Владе и владари уопште, радије постају жртвом или и насмјешком подлијех кортизана, но што би се предали у руке часну и поштену мужу, који би вазда био готов да жртвује све осим саме части и поштења свога. И по моме мњењу исти су они горе споменути узроци што наш Божидар, поред оноликијех сјајних по државу заслуга, не бијаше почашћен ни најмањијем државнијем редом! Него, што су сви државни редови, напрема љубави народној?... Шта ли су сва одликовања, напрема поштовању, које љубимац народни код свога народа стиче и ужива?... Његов је највећи орден данас: та љубав и то поштовање“ (Сундечић 1879: 43). ${ }^{3}$

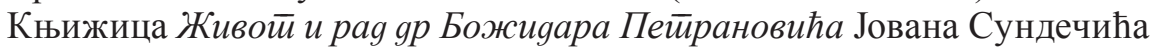
прије свега је израз ауторовог поштовања према једној истакнутој личности која је у историји далматинских Срба у деветнаестом вијеку оставила неизбрисив траг. Иако је своју студију писао са нескривеним осјећајем наклоности, Сундечић ни на једном мјесту није изневјерио одмјереност, истраживачку озбиљност и пријеко потребну дистанцу у списима оваквог карактера. Иако превасходно опредијељен да испише биографију Божидара Петрановића, он је на више мјеста приказао књижевноисторијски и шири историјски контекст дјеловања ове личности, без чега се њен значај не може адекватно оцијенити. Политички, просвјетни и културни рад Божидара Петрановића Сундечић сјенчи у широком контексту, али прилично увјерљиво, захваљујући, прије свега, Петрановићевом аутобиографском спису, који приказивању прибавља снагу аутентичности. Књижевне радове Петрановићеве његов биограф пописује и сажето описује, али готово никад не вреднује, осим онда када се ослања на оцјене других аутора. Завршетак студије о Петрановићу

3 У завршном дијелу студије о Петрановићу Сундечић не пропушта да наведе и то да је утемељивач Матице далматинске познавао више свјетских језика те доноси и попис његових дјела која су остала необјављена: припремљено друго, исправљено издање Истиорије књижевносиии, затим грађу за други дио ове књиге, Чериее криминалноїа закона, писаног за кнежевину Србију још 1841. године, Земљойис те Петрановићеве биљешке о његовом посланичком раду у Бечу и Кромјерижу. 
Сундечић исписује у интимистичком тону, због чега добија обиљежја занимљиве критичке прозе у којој се између двојице блиских људи не укида дистанца, док Петрановић, управо захваљујући наведеној промјени приказивачког тона, бива оживљен и умјешно приближен читаоцима.

5. Године 1885. Јован Сундечић је у Загребу објавио Тужну књиіу, једну од најнеобичнијих у читавој српској књижевности. У њеном предговору пјесник и неутјешни отац пише: „Она је још слатка одуга успомени двају синова, двају врлијех подмладака, које је зла и немила судбина, као двије ките и зелене гране, непоштедно од срца отченула старцу оцу и сјетној остарјелој мајци“ (Сундечић 1885: 2). Зборничког карактера, књига садржи биографије пјесникових преминулих синова Велимира и Пера, Сундечићеву пјесничку збирку Oguсаји роgителељскоїа сриа, као и књигу пјесама његовог преминулог сина Пера Сундечића под насловом Срие и љубав. ${ }^{4}$

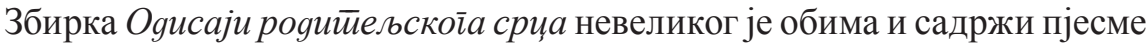
написане у кратком временском периоду. Прва пјесма, под насловом Њивио сам ивије $\bar{u}$, написана је у Котору 1 . децембра 1883. године, а посљедња, под насловом И још јеgна іорка суза, у истом граду, на Усјековање 1884. године. У низу пјесама Сундечић успјешним поступком поетске алегоризације („Њивио сам цвијет“, „Побољела тица мала“" и другима), наговјештава синовљеву болест и неизбјежну смрт, настојећи да, њеним измицањем у имагинарни простор, што више од себе удаљи ту тешку спознају. Упркос том поступку, Сундечић се опредјељује и за лирску конкретизацију своје патње, која посредством опредмећених слика бива предочена читаоцу. У пјесми $O j !$ она мамй $a$ наглашава како чак ни бијег из стварности у подручје измаштаног не може да га удаљи од тешког и свеприсутног бола, појачаног усљед осјећаја беспомоћности. Бол за умирућим сином, кога пореди са жарким сунщем, не може се изједначити ни са чим другим што је пјесник у животу искусио, иако га је судбина шибала бројним невољама.

Пјесник је на једном мјесту захвалан пријатељима на бризи и утјешитељским ријечима, док недуго затим казује како је његова бол безмјерна:

„Али срцу... али срцу пусту,

Родитељском срцу кад зазебе

${ }^{4} \mathrm{O}$ својој породичној трагедији Сундечић је оставио трага и у предговору књизи Миље и омиље или Милица и Невенка, у чијем предговору пише: „Међутијем, мене сустигле моје ужасне невоље: губитак мојијех предрагијех и врлијех синова̂; особито мога дивног Пера̂: моје послје Бога, највеће на свијету узданице; а до мало опет и губитак премиле и премладе моје невијесте у Петрограду - ти су ме моји љути јади били тако оборили и поништили да бијах на све, па и на самога себе заборавио. Очит ми је свједок моја Тужна књиїа, каквијех сам се неподносивијех мука̂ у тоิ доба намучио и једва-једвице себе надвладао да се не обезумим, или да не подлегнем најкрућему очајању. И само чуство према Невенки било је тад претрнуло и угвозоденило се у пренемило рањеном мојему нједру... Ох, Боже!... ужасни ли су у животу такови тренутци!““(Сундечић 1893: 30). 
И претрне кад животом сина:

Све је црно у наоко себа...

Мрко му је у по б’јела дана:

Магли му се кад и ведро влада;

Пркоси му сјај сунашца жарка,

И утјеха на њ ка' камен пада...

А ох ти га оном, кога тјеше!...

Тјешилице - њем су жаочице;

Подсјете га на златне тренутке

Па му сузам облије се лице;

Из прса ми тешки уздисаји

Отисну се отисну јауци,

Ма и да се значајеви тврди

И јунаци познају на муци.

Је л' јунаштво?... или је слабоћа:

Моћ прегоријет зјеницу од ока?...“ (Сундечић 1893: 51).

Пјесник се обраћа природи, молећи је да му поштеди сина, а да

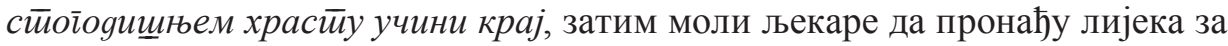
болест његовог обољелог сина. Свјестан узалудности тих молби, он у пјесми Данас sуяg саопштава своје мисли о крхкости људског знања, конкретније речено, његовој ограничености и суштинској немоћи пред крајњим искушењима живота и смрти:

„Данас људи много свашта кажу

О човјеку, о св’јету, о Богу:

И то само учевношћу зову,

Кад исхитрит њешта нова могу

И порећи што су велеуми

Кроз вјекове вјеровали тврдо

Пењући се у границам ума

На високо људског знања брдо...

$[\ldots]$

Поред свега огромног наука

Малени смо и премали знамо

Излудимо - пошто премудримо:

К вищем летећ - у ниже падамо.

Безвјерни смо: а вјере нам треба:

Вјерујемо у крај мртве вјере,

Ми у нищйо... и нищйоро је юещитио:

Опет вјера - ма да вјеру ждере...“ (Сундечић 1893: 56 - 57).

Кулминација пјесникове боли и резигнације животом, опште клонулости и разочарања, наступа након смрти сина Пера:

„Све ме тужи - што ме кружи;

Све ме мори - што ме збори;

Све што пишти - мене тишти; 
Све ме једи - што ме гледи:

Јад је голем, крупан, страшан,

Јад је крвав мој!...“ (Сундечић 1893: 63).

Тешко да се у српској поезији може издвојити овако искрен, болан крик. У одређеном смислу је то пјесма Саве Мркаља, углавном позната под насловом Jao! Jao! Jao! йристиа йуйа, која своје пориве има дубоко посађене у овом пјеснику и његовој природи, у неспоразуму са свијетом у којем је видио само пакост и зло. Сундечићев болни крик лишен је свих наноса срџбе, љутње, озлојеђености (тако карактеристичних за романитчаре, Јакшића, на примјер!), то је незадрживи родитељски бол, који потреса снагом искрености и, као такав, нехотично призива дубоку људску саосјећајност.

Најзад, у Оوисајима рояийељской сриа, у више пјесама, примјетан је смјерни молитвени тон. Као пјесник који је био свештеник, Јован Сундечић утјехе родитељском болу налази у молитвеном укрепљењу и хришћанској визији смрти као саставног дијела људске егзистенције:

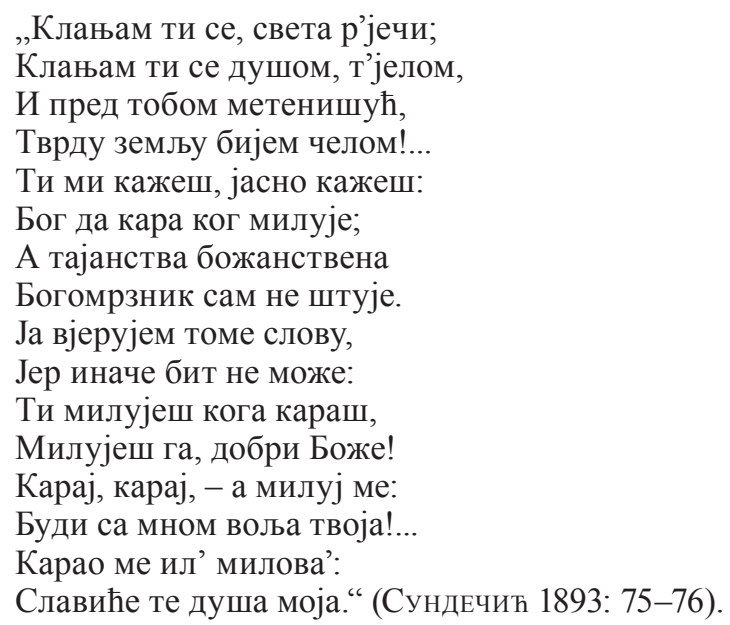

Сундечићеве пјесме из збирке Ogисаји роgииеељскої срия настале су за вријеме боловања и непосредно послије смрти његовог сина Пера Сундечића. У њима пјесник из дубине свога болног бића, срастао са патњом, исписује пјесме које су вјеродостојно свједочанство о највећој трагедији која може да задеси једног човјека. У пјесмама Сундечић проналази макар тренутни мир изранављеној души, свјестан да тим стваралачким напором, у којем има и светости и проклетства, подиже најтрајнији памјатник своме сину, а своју породичну трагедију из конкретног тренутка измјешта у умјетничко надвријеме.

6. Јован Сундечић је 1882. године објавио збирку љубавне поезије под насловом Љубав и цвијеће. Једанаест године доцније, штампао је зборник својих нових и већ објављених пјесама под насловом Миље и омиље или 
Милица и Невенка, књигу која га на репрезентативан начин представља као пјесника љубавне инспирације. У укупном Сундечићевом пјесничком опусу, поменута збирка је његово највредније дјело.

И једну и другу књигу љубавних стихова Сундечић је пропратио занимљивим предговорима. У предговору збирци Љубав и цвијеће пјесник износи неколика запажања која могу бити од користи за освјетљавање његове поетике. Љубав је, тврди наш пјесник, као и толики прије њега, осјећање које је снажан покретачки импулс за умјетничко изражавање. Тај љубавни пјеснички занос може бити толико снажан да пјесника из њега ни његов ум не може да „тргне“. Занесен љубављу и љепотом, као њеном „дружбеницом“, пјесник је загонетка („неиспитив“) и сам себи. Из тога тајанства, наставља Сундечић, настаје љубавна поезија. Један одломак из књиге Љубав и иввиеће посебно је занимљив, па га овдје наводимо у цјелини: „Све што бива, ништа без њешта не бива. И пјесникова је душа саздана да слави и да преузноси љубав. Народности и домовини, слози и братимству, пјесник зато пјева - што их љуби; као што пјева омиљелој му љепоти, зато, што љепоту љуби. Љепота и љубав раме уз раме успоредно се мичу. Пјесник с неба своди сјајне звијезде, бира најмирисније и најубавније по ливади цвијеће, да љубави плете вијенце и обоิце, да јој напонита прса кити и да јој свилокосу главу круни. Диван ли је сликар пјесник, кад узме да слика дражести и милине љубави! Његова разгријана машта проналази нове и свјеже облике; граби од жаркога сунца живоћу и блиставило његовијех боја: па слика љубав у видовима пуним божанствене њежности и милине.

Тражи да му свака црта с цртом у потпуном сугласју буде и улаже свуколику своју помњу да у свој живопис улије ону живахност која привлачи, плијени и заноси. И реци пјеснику да је то све гола сања и опсјена: залуду ти мука... Што је једаред пјесникова машта оживотворила то је већ сушта истинска истина у његовијем зеницама. Пјесник живо слика и радости и туге и љубави; залијеће се у небо и спушта се у пакао; бори се са собом, бори се с љуцком пакости, бори се с цијелим свемиром. Он сву читаву природу премеће уздуж и попријеко, проучава је и - из ње све учи. Силна је снага у пјеснику и чврста као челик воља. Пјесник се никаквоме труду не подаје, нит' олако малаксати може. То је наслиједио од онога, који му је таку душу удахнуо“(Сундечић 1882: 10-11).

Битно друкчијег карактера је пјесников предговор збирци Миље и омиље или Милица и Невенка; то је јединствено љубавно разоткривање једног српског пјесника који нам, без устезања, казује о женама које је на различите начине волио, које су обиљежиле његов емотивни живот и биле подстицај за његове „љубавнице“ (како назива љубавне пјесме). Тим разоткривањем, оспољавањем најзапретенијих закутака пјесниковог интимног бића, пред нама се поменута збирка разлистава као „отворена књига“, јединствен, како пјесник наводи, „љубавни роман“. Због те интимности, ова збирка се чита као искрена и аутентична исповијест, што снажно појачава њена умјетничка својства. Раскривајући свој интимни свијет, Сундечић, као баштиник 
романтичарске пјесничке традиције, брише разлику између сопственог бића и умјетничког свијета пјесме. Зато се његове најбоље пјесме читају као лиризоване исповијести, у пјеснички универзум пренесена непосредна лична искуства. Тематско-мотивски распон, ритмичко-мелодијски и метрички регистар, емотивни набој његових љубавних пјесама сав је у кругу романтичарске поетичке формације.

Како нас у предговору своје репрезентативне збирке љубавних пјесама исцрпно информише пјесник, његова љубавна осјећања везана су за три жене, „три љубави“. Прва је дјечачка симпатија, која је више слутња и чежња, како и бива у том узрасту, у којем се чула необуздано буде али још увијек не обликују у конкретан доживљај; друга је његова супруга, са којом је изродио једанаесторо дјеце и којој, истина, посвећује свега четрнаест пјесама; трећа је његова муза и вила, удата жена из Котора, знатно млађа од њега, којој он надијева име Невенка. Сусрет са њом је од изузетне важности за пјесника, јер га снага тог међуодноса, којем до краја остаје страна било каква чулност, окрепљује, спасава тешке душевне болести. Кроз њен лик, лик „идеалне драге“, пјесник ће славити саму љубав, али, пошто ће се млада упокојити, и лик „мртве драге“, која ће га мотивисати да се из дубине свога очаја спасава поезијом, славећи вјечну љубав и љепоту.

У „Уводници“ Љубави и цвијећа, пјесник у једном узвишеном занесеном осјећању пјева:

\author{
„Жену, пјесмо, вино \\ Ко не љуби, тај \\ Не зна шта је живот, \\ Што л’ на земљи рај;““ (Сундечић 1882: 23).
}

саопштавајући нам упоришта и постојане вриједности свога умјетничког универзума.

Кратка пјесма, која би се условно могла одредити као Сундечићев „пјеснички програм“, носи наслов Миља и омиља и гласи:
„Пјесникова душа - рад љубави љуби;
Љубљена жена: љуби ли?... и жуди...
Њезина жудња - не стигне ли циља;
Залуд су свака - миља и омиља,
И празну љубав одбиће од груди.“

Љубав је за пјесника незатајна и нескривена, ако је аутентична; она подстиче на машту и чини да предметна стварност, преломљена кроз призму љубавног сензибилитета, буде сасвим другачија:

„При маштену блиставилу твоме

При којем је љепше - што је лијепо,

При којем је драже - што је драго,

И милије - што је срцу мило!“ (Сундечић 1893: 15). 
Симболика очију важна је у Сундечићевим љубавним пјесмама: кроз поглед се остварује љубавни сусрет, и иначе сусрет бића са бићем, из очију избија живи небески йламен; у очима, и посредством њих, огледају се чежње и страсти, нескривени еротски пламен, на примјер, у пјесми Заіррљај $u$ йољубаи, чија прва строфа гласи:

\author{
„Реци право, славуљицо моја! \\ Под пољупцем ватренијем 'нако, \\ Да л’ су ти се икад прије груди \\ У животу задахтиле тако?“(Сундечић 1893: 37).
}

У том заносу пјесник ваја и лик идеалне драге, у пјесми карактеристичног наслова „На њезину слику“, у којој се у јединствену визију стапају стварне жене и оне из пјесникове имагинације, различитим подстицајима надахнуте пројекције:

\author{
„Све што је Бог красота \\ У својим рукама има', \\ И рајских дивота \\ Са рајским дражестима. \\ Све је у лице твоје \\ Улио тај мили бог, \\ У жару љупце своје, \\ Раскошом обиља свог“ (Сундечић 1893: 38).
}

Очаравајућа љепота је увијек рајска, носи снажан печат обиљежености оностраним. Треба примијетити, поводом ове, али и бројних других Сундечићевих пјесама из овога круга, да пјесничка вјештина знатно заостаје за снагом емоције и искреног доживљаја, који претиче језик и онемогућава његово аутентично пјесничко „записивање“.

Посљедња цјелина збирке Миље и омиље садржу преко шездесет пјесама које су настале након Невенкине смрти, од почетка 1891. године. Сундечић ове пјесме, према њиховој тематици и доминантном тону, назива „јадиковке“. У њима су обрађени бројни мотиви: смрти, љепоте, боли, док као осјећања преовлађују резигнација, туга, обесхрабреност и, понајвише, усамљеност. У пјесми A ја осйах завршна строфа гласи:

„А ја остах, осјечено дрво,

Да размишљам о усуду жића;

Да размишљам и да вјеру стичем.

Е у свиету нема нами бића“ (Сундечић 1893: 177).

Своју усамљеност пјесник конкретизује прецизном сликом („осјечено дрво“), док поводом смрти вољеног бића размишља о комплексним питањима овостраности и оностраности, и то више као вјерујући човјек неголи романтичарски пјесник. С друге стране, у пјесми $A x$ ! Без йебе, без тог „вишег“ 
набоја и пренесених значења, крајње реалистички прецизно дочарава се усамљеност. Снага осјећања дочарана је најприје кроз болни крик (Јој!) те кроз интерпункцијска рјешења:

„Ах! без тебе Невко,

Без твог ока, јој!

Самотан се чини

Мени живот мој!“‘ (Сундечић 1893: 183).

Разрјешење и својеврсну утјеху пјесник, ипак, проналази! То се види из изванредне пјесме Па $\bar{u} a g$ кажи и йјеснику, која у цјелини гласи:

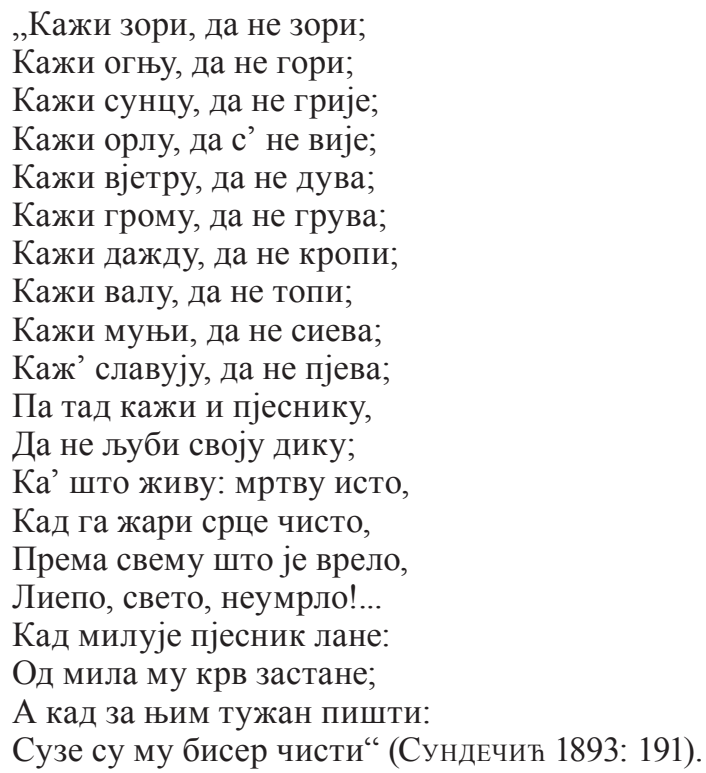

Пјесник своју вилу (,„дику“) подједнако воли и љуби мртву као и живу. Јован Сундечић на овај начин налази смирај болној и измученој души, потврђујући своју вјеру у искупитељску снагу поезије, пред којом свих времена разлике ћутее.

7. „Сундечић је за живота био подједнако слављен и омаловажаван, често непримјерено величан и још безразложније одбациван, а након смрти је потонуо у потпуни заборав“"(МАксимовић 2013: 35). Ове ријечи књижевног историчара Горана Максимовића, аутора књиге Заборављени књижевници, сугеришу да је неправда заборава једно од трајних обиљежја српске књижевноисторијске свијести. Читалац овог избора из опуса Јована Сундечића, у оквиру едиције Срйска књижевности у Босни и Хериейовини“, вјериће се да је ријеч о аутору који је неправедно заборављен и чије дјело, поготово 
у једном оваквом антологијском презентовању, заслужује поштовање и пажњу. Свештеник, пјесник, културни посленик, покретач и уредник књижевних листова и календара, повјерљиви дипломата кнеза Николе, Сундечић се одликовао великом радном енергијом. Када је ријеч о пјесничком дијелу његовог опуса, онда неизоставно треба констатовати сљедеће: његове морално-поучне и пјесме које су испјеване под снажним утицајем наше епске поезије данас, прије свега, имају књижевноисторијски значај и свједочанство су колико преображаја једног пјесника толико и еволутивних путева новије српске лирике. Зар и епске пјесме Бранка Радичевића, уз сав ризик било каквог поређења ових стваралаца, вриједносно знатно не заостају за његовом лирском поезијом и зар ни оне не представљају само романтичарски „дуг“ своме времену? Епске пјесме Јована Сундечића испјеване су без оригиналности и углавном представљају неувјерљиви одјек угледања. Па ипак, у њима просину занимљиви описи, динамичне нарације, живописни карак-

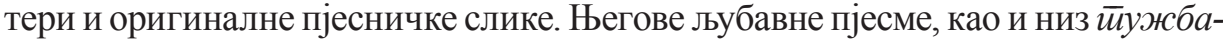
лица, испјеваних поводом преране смрти двојице синова, представљају аутентичног лиричара, снажних емоција, веома често вјешто упјесмљених. Регистар осјећања у тим пјесмотворима је прилично богат, тематско-мотивски склопови инвентивни, тон аутентичан (само у ријетким моментима патетичан), а укупни ефекат, и онда када је ријеч о дужим остварењима, кондензован и снажан.

Сундечићеви текстови о Петрановићу и Сарајлији откривају ствараоца који се са поштовањем односио према својим знаменитим савременицима, док његови предговори објављеним пјесничким збиркама предочавају ствараоца који културно-просвјетни рад није одвајао од укупног друштвеног и националног напретка, а стварање поезије од интензивне мисли о њеним недокучивим тајнама.

\section{ИЗВОРИ}

СтеријА, Поповић Јован. Даворје. Вршац: Књижевна општина Вршац, 1993.

СундЕчић, Јован. Изабране ӥјесме. Приредио Хуго Бадалић. Загреб: Матица хрватска, 1898.

СундЕчић, ЈовАн. Миље и омиље или Милииа и Невенка. Загреб: Дионичка тискара, 1893.

Сундечић, ЈовАн. Живот и рад др Божидара Петрановића. Словинаи 12 (1878): 124-126.

Сундечић, ЈовАн. Тужна књиїа. Ogисаји роgийељскоїа сриа. Загреб: Дионичка тискара, 1885.

Сундечић, Јован. Љубав и ивијеће. Дубровник: Тискара Драгутина Претнера, 1882. Сундечић, ЈовАн. Живот и рад др Божидара петрановића. Словинаи 1 (1879): 12-14. Сундечић, Јован. Химна и бесјеgа у славу Сима Милуйиновића Сарајлије. Сарајево: Прва српска штампарија Ристе Ј. Савића, 1893. 


\section{ЦИТИРАНА ЛИТЕРАТУРА}

Божовић, М. ПетАР. Јован Сундечић. Београд: Млада Србија, 1928.

Георгијевић, Крешимир. Јован Сундечућ. Лейойис Майище срӣске 102 (1928).

Грчић, Јован. Иситорија срӣске књижевносӣи. Нови Сад: Књижара Браћа М. Поповића, 1903.

Деретић, Јован. Истиорија сритске књижевностии. Зрењанин: Sezam book, 2007.

МАксимовић, Горан. Заборављени књижевници. Пале: Српско просвјетно и културно друштво Просвјета, 2013.

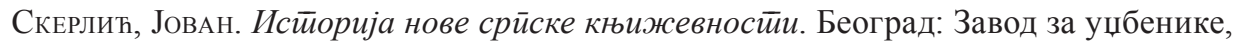
2006.

Сундечић, ЈовАн. Јован Сундечић: свещйеник, ӥјесник, gийломайа, приредио Душко Певуља. Бањалука: Народна и универзитетска библиотека Републике Српске, 2009.

Цар, МАрко. Јован Сундечић. Леӣойис Майице срӣске 215 (1902): 1-32.

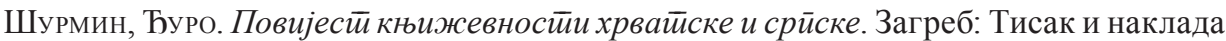
књижара Лав. Хартмана, 1898.

Duško V. Pevulja

POETRY AND POETICS OF JOVAN SUNDEČIĆ

Sum mary

The paper offers insight into the poetic stance of the unjustifiably marginalized poet Jovan Sundečić and it analyzes the dominant artistic features of his vast poetic opus. The presentation of Sundečić's poetics took into consideration his poems that talk of poetic creation as well as the texts on this topic. Sundečić's poetic opus is analyzed with respect to the dominant complexes of the thematic and motive axes, linguistic particularities, artistically recognizable elements and frequent changes that his creative opus went through during several decades. A special focus in this paper put on Sundečić's study on Božidar Petranović, which occupies a prominent place in the opus of this priest, diplomat and poet. At the same time, the paper indicates various forms of reception of Sundečić's diverse work and mentions possible causes for the neglect of his opus in Serbian literary history.

Универзитет у Бањој Луци

Филолошки факултет

dusko.pevulja@flf.unibl.org 